\section{Managing cleft lip and palate}

\section{Editorial proves controversial}

EDITOR,-In their two year Medline search for studies on the results of cleft surgery Tony Markus and Peter Ward Booth found just one British study, and they criticise the lack of British studies. Six studies on primary and secondary surgery and outcome analysis are noteworthy, ${ }^{2-7}$ as is a book on speech. ${ }^{8}$

Citing just the Eurocleft study, which included two British centres, Markus and Ward Booth state that British results are poor. This is not true in other British studies. ${ }^{910}$ The authors neglect to mention that the two centres with the best results in the Eurocleft study used different surgical techniques (none like Markus's) and high volume operators (none of them maxillofacial surgeons). On high volume operators Markus and Ward Booth are incoherent. They move from implying that specialist high volume operators are preferable to stating that high volume operators and large, centralised units do not guarantee good results, while high volume maxillofacial surgery exists in district hospitals, which are well placed to provide a comprehensive service.

European countries, including Britain, have made advances in cleft surgery. "Continental Europe may do it better"- - or it may not. Early cleft bone grafting was once strongly advocated in Germany, but further studies in, for example, Britain and Germany led to its being abandoned." For years the technique of delayed hard palate closure of Schweckendiek in Germany was considered to be good, until it was reported to give poor results in terms of speech. ${ }^{12}$ Other studiesfor example, one in Britain - had earlier shown worse speech after delayed hard palate closure. ${ }^{1}$

Two French cleft surgeons, Malek and Delaire, are known internationally. Delaire never kept detailed records and did not publish his results. Nevertheless, Markus uses Delaire's technique and states that it "results in better function and more normal growth and development." ${ }^{\prime \prime}$ There is no evidence for this in the references given.

Markus labels his surgery functional surgery, as if functional surgery for clefts is new. This is not so. Functional surgery for clefts, based on studies of function and anatomy, has been done for decades. ${ }^{11}$

"Studies comparing this technique with those commonly used in Britain suggest that functional surgery produces consistently better results." This is not true. The reference cited ${ }^{13}$ describes a treatment regimen different from that used by

\section{Advice to author}

We prefer short letters that relate to recently published article and we are unlikely to publish letters longer than 400 words and containing over five references. Letters may be shortened. Your letters should be typed with double spacing and include a word count. All authors need to sign the letter and provide one current appointment and address. We encourage you to declare any conflict of interest. Please enclose a stamped addressed envelope if you require an acknowledgment.
Markus. The study patients were compared with historical controls, whose lip repair is not described in detail, whose palate repair is not known to be used by anyone in Britain, ${ }^{14}$ and whose surgery was performed later than is now common in Britain. ${ }^{14}$ One surgeon has also had problems, including a "major problem" with fistulas, with the Markus technique. ${ }^{15}$

Markus and Ward Booth are right to question everything. They must also be questioned. As a surgeon, I am embarrassed by their indifference to facts and clear thinking. It will be difficult to believe them in future. I am disappointed that the $B M \mathcal{F}$ published their superficial, misleading, and self promoting piece. Patients, parents, and others deserve a better discussion of the multidisciplinary issues of cleft lip and palate.

M JTIMMONS

Bradford Royal Infirmary

Consultant Bradford Royal In

1 Markus T, Ward Booth P. Managing cleft lip and palate. $B M f$ 1995;311:765-6. (23 September.)

Zhu NW, Senewiratne S, Pigott RW. Lip posture and mouth width in children with unilateral cleft lip. $\mathrm{Br} \mathcal{F}$ Plast Surg 1994;47:301-5.

3 Jiginni V, Kangesu T, Sommerlad BC. Do babies require arm splints after cleft palate repair? Br f Plast Surg 1993;46:681-5.

Sommerlad BC, Henley M, Birch M, Harland K, Moiemen N, Boorman JG. Cleft palate re-repair-a clinical and radiographic study of 32 consecutive cases. Br f Plast Surg 1994;47:406-10.

5 Mackay F, Bottomley J, Semb G, Roberts C. Dentofacial form in the five-year-old child with unilateral cleft lip and palate. Cleft Palate Craniofac 7 1994:31:372-5.

6 Sell D, Harding A, Grunwell P. A screening assessment of cleft palate speech (Great Ormond Street speech assessment). Eur 7 Discord Commun 1994;29:1-15.

7 Peat BG, Albery EH, Jones K, Pigott RW. Tailoring velopharyngeal surgery: the influence of etiology and type of operation. Plast Reconser Surg 1994:93:948-53.

8 Grunwell P, ed. Analysing cleft palate speech. London: Whurr, 1993.

9 Christie FB, Stirrups DR, Mackenzie JS, Lawrence GM. An orthodontic evaluation of 16-year-old males with an original complete unilateral cleft lip and palate problem repaired during the neonatal period. Br f Plast Surg 1991;44:557-61.

10 Cussons PD, Murison MSC, Fernandez AEL, Pigott RW. A panel based assessment of early versus no nasal correction of the cleft lip nose. Br f Plast Surg 1993;46:7-12.

11 Millard DR Jr. Cleft craft. Vols 1, 2, 3. Boston: Little Brown, 1976-80.

12 Rohrich RJ, Byrd HS. Optimal timing of cleft palate closure: speech, facial growth and hearing considerations. Clin Plast Surg 1990;17:27-36.

13 Joos U. Skeletal growth after muscular reconstruction for cleft lip. Alveolus, and palate. Br $f$ Oral Maxillofac Surg 1995;33: 139-44.

14 Asher-McDade C, Shaw WC. Current cleft lip and palate management in the United Kingdom. Br $\mathcal{f}$ Plast Surg 1990;43:318-21.

15 Pospisil OA. Personal experience with primary functional dual repair of cleft lip and palate [abstract]. $\mathrm{Br} \mathcal{F}$ Oral Maxillofac Surg 1995;33:122.

\section{Trials of management are inevitably long}

EDrToR,-In their editorial Tony Markus and Peter Ward Booth ${ }^{1}$ seek to discredit the work of most British surgeons working in cleft lip and palate on the basis of results in patients treated in the 1970 s published by Shaw et al. ${ }^{2}$ They imply that no lessons have been learnt and state that the "functional repair" of Delaire produces vastly superior results. However, Delaire failed to publish his results, and Markus and Ward Booth merely reiterate his hypothesis. The almost identical technique of Malek produced as good but not better results than those achieved in Toronto by the Langenbeck technique when assessed by an independent authority. ${ }^{3}$
But let us suppose Delaire is right. It will be appreciated that one cannot take up every good idea that comes along when one is in the middle of a trial. In a career that started in 1969, with a caseload equivalent to that of Markus, it has taken me nearly 25 years to get articles published on a sufficient number of cases treated 10 years ago by the Veau technique for the findings to be significant. With three times the caseload treated in the 1980 s by the Langenbeck technique, a comparable series will be reported in a mere 15 years. A final cohort, which I began to gather in $1989,{ }^{4}$ is being compared with 5 year olds treated by the Langenbeck technique. Treatment in this final cohort embodies Malek's and Delaire's principle of restricting mucoperiosteal undermining to the palatal shelf mucosa. If an overwhelming increase in the ideal relation among the incisor teeth (Angle class I) is found in this group it will encourage surgeons to concentrate on this aspect of planning treatment. But these will be prepubertal results (as were those of Joos) obtained sequentially, not synchronously. In the end only a randomised prospective trial will elucidate this problem.

As is to be expected in papers written by dentists, facial growth is considered to be the preeminent outcome. It is unfortunate that speech, appearance, and social integration, which are the pre-eminent concerns of patients, are more difficult to evaluate, though results with regard to speech that are achieved in Britain compare extremely favourably with any in the English speaking world.

RW PIGOTT

Department of Plastic Surgery Consultant plastic surgeon Frenchay Hospital,

Bristol BS16 1L

1 Markus T, Ward Booth P. Managing cleft lip and palate. $B M$ 1995;311:765-6. (23 September.)

2 Shaw WC, Dahl E. Asher-McDade C, Brattstrom V, McWilliam J, Mars M, et al. Eurocleft. A six centre international study of treatment outcome in patients with cleft lip and palate. Cleft Palate Craniofac $F$ 1992;29:413-8.

3 Ross B. Growth of the facial skeleton following the Malek repair for unilateral cleft lip and palate. Cleft Palate $\mathcal{F} 1$ 995;32:194-8.

4 Murison MSC, Pigott RW. Medial Langenbeck. Experience of a modified von Langenbeck repair of the cleft palate. A preliminary report. Br f Plast Surg 1992;45:454-9.

\section{Specialised multidisciplinary team can solve problems of distance}

EDrroR,-We believe the editorial on managing cleft lip and palate to be misleading. ${ }^{1}$ The Eurocleft study indicated that the outcome of repair of cleft lip and palate was inversely proportional to the number of operators. ${ }^{2}$ To suggest that cleft surgery services should be devolved to local hospitals with multiple operators undertaking few procedures therefore seems illogical and is also at odds with the situation in continental Europe, where cleft surgery is concentrated into a small number of centres.

Anatomical specialisation seems logical, but the suggestion that high volume operators in adult maxillofacial surgery are the best qualified to undertake primary cleft surgery in infants denies the differences in the nature of the tissues (which change appreciably with age), the surgery itself, and the management of children compared with that of adults. In Britain most primary cleft surgery is undertaken by plastic surgeons working 